\title{
HYDROGEL FORMULATION FROM CALOTROPIS GIGANTEA PLANT EXTRACT AGAINST FOOT ULCER CAUSING BACTERIA IN DIABETES
}

\section{RAMACHANDRAN AM*, SENTHIL PRABHU S, DEVAKUMAR J, RENGARAMANUJAM J, KARTHIK SUNDARAM S, MAHENTHIREN R, VARSHA TK}

Department of Microbiology, Dr. N.G.P. Arts and Science College, Coimbatore, Tamil Nadu, India. Email: luxyram40@gmail.com

\author{
Received: 20 February 2021, Revised and Accepted: 29 September 2021
}

\author{
ABSTRACT \\ Objective: The objective of present study was to develop hydrogel formulations loaded with Calotropis gigantea leaves extract.
}

Methods: The prepared hydrogel formulations were compliance with their color, odor, homogeneity, $\mathrm{pH}$, and spreadability.

Results: As all the formulations were complies with the all parameters and it can be suggest as a Good antibacterial gel. It is evident that, ethanolic extract of Calotropis gigantea showed a maximum inhibitory zone against bacteria associated with foot ulcer.

Conclusions: The In vitro studies showed a quantity dependent increase in antibacterial activity against foot ulcer causing bacteria, a contraction which is higher than that produced by the control groups. These contractions were statistically significant ( $<<0.05$ ), during the study with leave extract against foot ulcer causing bacteria in diabetes.

Keywords: Diabetes mellitus, Calotropis gigantea, Hydrogels, Formulation, Hydrogel.

(C) 2021 The Authors. Published by Innovare Academic Sciences Pvt Ltd. This is an open access article under the CC BY license (http://creativecommons.org/ licenses/by/4.0/) DOI: http://dx.doi.org/10.22159/ajpcr.2021v14i11.37147. Journal homepage: https://innovareacademics.in/journals/index.php/ajpcr

\section{INTRODUCTION}

Diabetes mellitus represents a major public health threat worldwide. A serious complication of diabetes is the development of foot ulcers which, when they become infected, are the most common cause of diabetesrelated hospital admissions and a leading cause of the lower extremity amputation. Diabetics with ulcers commonly experience infection with Gram-positive organisms such as Staphylococcus aureus, Streptococcus pyogenes, and Enterococcus faecalis, and Gram-negative organisms such as Pseudomonas aeruginosa, Escherichia coli, Klebsiella pneumoniae, and Serratia species [1]. There is a continuous need of the development of new effective antimicrobial drugs because of the emergence of new infectious diseases. Herbs and plants have been in use as a source of therapeutic compounds traditional medicinal system since ancient time. Hence, we have chosen a plant which has number of antimicrobial compound [2] such as Calotropis gigentica which is normally identified as weed plant is a wasteland plant belonging to Asclepiadaceae family. It is a 3-4 m tall shrub with milky latex. Bark ash colored, leaves opposite, decussate, sessile or subsessile; flower 2-4 cm across, purplish white, complete, fruit follicles, seed numerous, broadly ovate, and plano-convex. At present, the flowering parts of the plant prescribed to heal various bacterial infections. Hydrogel base is a critical factor to produce preparations having good physical properties and assist the process of wound healing in patients. This paper provides basic information on the antimicrobial activities of $C$. gigantea against bacterial pathogens which are often associated in foot ulcer in diabetes and the formulation of hydrogel.

\section{METHODS}

Selection and authentication of plant species

The plant Calotropis Gigantea was chosen and the extracts from its leaves were used for the complete work, which was authenticated by the Department of Botany, Govt Brennen College, Thalassery, Kerala. The authentication number is BSI/SRC-3/27/2019.

Isolation and purification of active factors from the selected plants The leaves of the plant were collected, shade dried, and ground to form a fine powder. The powder was then subjected to solvent extraction using ethanol, butanol, and acetone. A $10 \% \mathrm{~W} / \mathrm{V}$ of the powder is mixed in each of the selected solvents, and left as such in a shaker incubator for $24 \mathrm{~h}$. After incubation the content is filtered using a Whatman filter paper and the filtrate mixture containing the specified active factor was dried out to concentrate the active factor [3]. The hydrogel obtained from powdered dried leaves may have potential in various drug delivery systems [4]. The dried powder is used further for estimating the presence of various phyto chemical compounds and in the production of hydrogel.

\section{Phytochemical constituent's determination}

The following phytochemicals such as tannins, alkaloids, flavonoids, saponins, steroids, terpenoids, carbohydrate, and proteins were determined by the methods described by Mikail and Venkitachalapathi kalaiselvi $[5,6]$.

Determination of antimicrobial activity against the selected clinical specimens

Microbes were procured from KMCH Clinical Laboratory, Coimbatore. Among the organism based on the predominance in causing foot ulcer the organisms mentioned in the following was used for further antibacterial analysis such as Staphylococcus aureus, Pseudomonas aeroginosa, Escherichia coli, Klebsiella pneumonia, Streptococcus pyogens, Enterococcus faecalis, and Serratia sp.

Development of hydrogel containing extracts of Calotropis gigantea Required quantity of carbopol-934 was slowly sprinkled with continuous stirring into measured quantum of water to get a uniform dispersion and then kept overnight for hydration. The accurately weighed amounts of plant extract along with other additives were poured in the fixed amount of hydrated Carbopol-934 dispersion (after incubation) with constant mechanical stirring. The solution is neutralized by slowly adding triethanolamine solution with constant stirring until the gel is formed. The quantity of ingredients is gradually increased up to three formulations (F1, F2, and F3) to detect the strength of the formulation effectively. Hydrogel formulations were made with different quantity of ingredients as mentioned in Table 1. 
Evaluation of properties of developed hydrogel [7]

The physical appearance was visually checked for the texture of hydro gel formulations and observations were recorded. The color of the formulations was checked against white and black background and documented. For analyzing the $\mathrm{pH}$ of the developed hydrogel, $10 \% \mathrm{w} / \mathrm{v}$ of the gel was dispersed in distilled water and stored for $2 \mathrm{~h}$. This solution was used for the measurement of $\mathrm{pH}$ of developed hydrogel. The measurement of $\mathrm{pH}$ of formulation was carried out in triplicate and the average values are recorded.

Gel is spreading on the skin at a particular area called spreadability. It is calculated using the formula:

$\mathrm{S}=\mathrm{ml} / \mathrm{t}$

Where, $\mathrm{m}=$ weight tied to upper slide, $\mathrm{l}=$ length moved on glass slide, and $\mathrm{t}=$ time taken to separate the slides completely from each other. Spreadability of the formulation was recorded. The hydrogel formulation whose spreadability had to be determined was placed over one slide. A second slide was placed over the slide in such a way that the formulation was sandwiched between them across the length of the slide $(6 \mathrm{~cm})$. Exactly $100 \mathrm{gm}$ of weight was placed up on the upper slide so that the gel formulation between the two slides was traced uniformly to form a thin layer. The weight was removed and the excess of the gel formulation adhering to the slides was scrapped off the bottom of the slide was attached on the apparatus board and the upper portion of the slide was tied with a string. Phenolics are essential metabolites which are playing vital role in the antioxidant activity [8-10]. $20 \mathrm{~g}$ load was applied by means of a simple pulley. The time taken for the upper slide to travel the distance of $6 \mathrm{~cm}$ and separate away from the lower slide under the direction of the weight was noted. This step was repeated for 6 times and the average was calculated for gel formulation.

Exactly $1 \mathrm{gm}$ of gel was accurately weighed and transferred to $100 \mathrm{ml}$ volumetric flask to which about $70 \mathrm{ml}$ of methanol was added and stirred followed by making up volume to $100 \mathrm{ml}$ with methanol. The content was filtered using filter paper $1 \mathrm{ml}$ filtrate was pipette out and diluted with methanol. Then the extract was estimated by using spectrophotometer.

\section{Statistical analysis}

All values are reported as mean \pm SEM the statistical differences between groups were determined by the Duncan multiple range test and analysis

Table 1: Hydrogel formulations with various quantity of ingredients

\begin{tabular}{llll}
\hline Ingredient & F1 (in g) & F2 (in g) & F3 (in g) \\
\hline C. gigantea extract & 1 & 1.5 & 2 \\
Carbapol 934 & 1.5 & 1.5 & 1.5 \\
Polyethylene glycol & 5 & 5 & 5 \\
Triethanolamine & 1.5 & 1.5 & 1.5 \\
Distilled Water (in ml) & 50 & 50 & 50 \\
\hline
\end{tabular}

F1, F2, F3- Formulations

Table 2: Phytochemical profile of Calotropis gigantea leaf extract

\begin{tabular}{lllll}
\hline S. No & Constituents & $\begin{array}{l}\text { Ethanolic } \\
\text { extract }\end{array}$ & $\begin{array}{l}\text { Butanolic } \\
\text { extract }\end{array}$ & $\begin{array}{l}\text { Acetone } \\
\text { extract }\end{array}$ \\
\hline 1. & Alkaloid & ++ & + & + \\
2. & Flavonoid & ++ & + & - \\
3. & Terpenoid & + & + & - \\
4. & Steroid & + & - & - \\
5. & Tannins & + & + & - \\
6. & Saponins & + & ++ & - \\
7. & Phenols & + & + & - \\
8. & Carbohydrate & - & + & - \\
9. & Proteins & - & - & - \\
\hline
\end{tabular}

+: Presence, -: Absence, ++: Excessive of variance also applied. A value of $\mathrm{p}<0.05$ was considered significant. Statistical analysis was performed using the SAS for Windows software.

\section{RESULTS AND DISCUSSION}

The extracts of Calotropis gigantea is said to have antidiabetic activity [8] and hence if the plant extract is capable of having an antibacterial activity too [9] the issue surrounding the treatment of diabetic foot ulcer would have additional leverage.

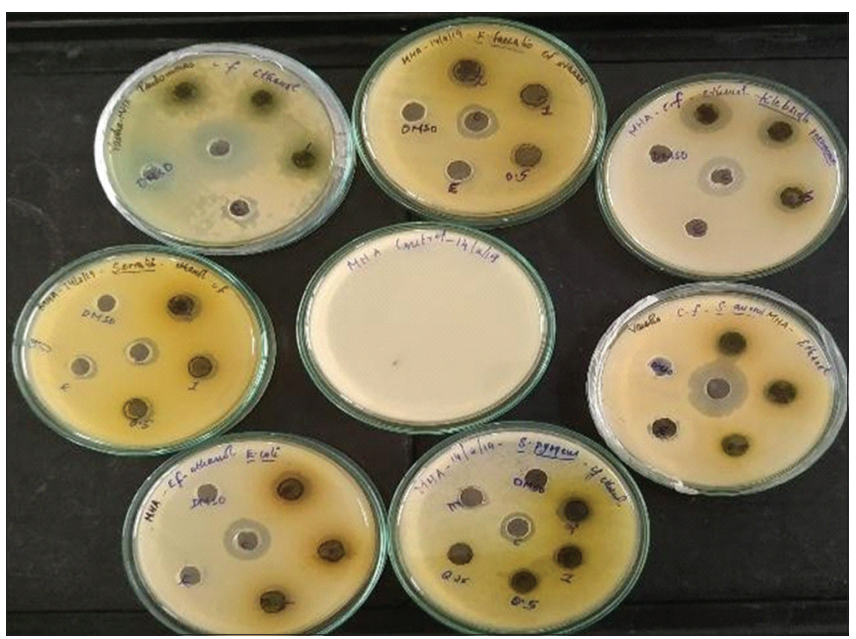

Fig. 1: Zone of inhibition by the ethanolic $C$. gigantea

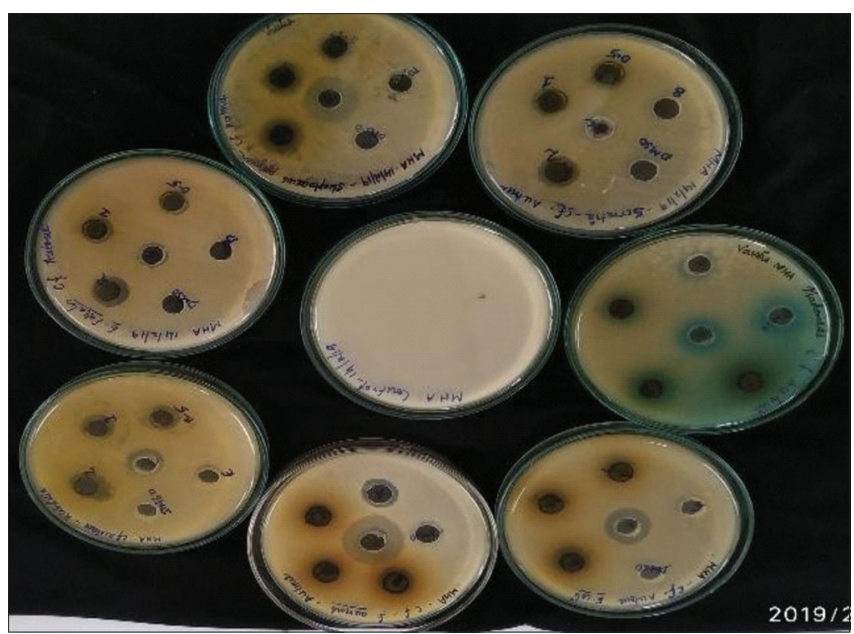

Fig. 2: Zone of inhibition by But anolic extract of extract of $C$. giganted

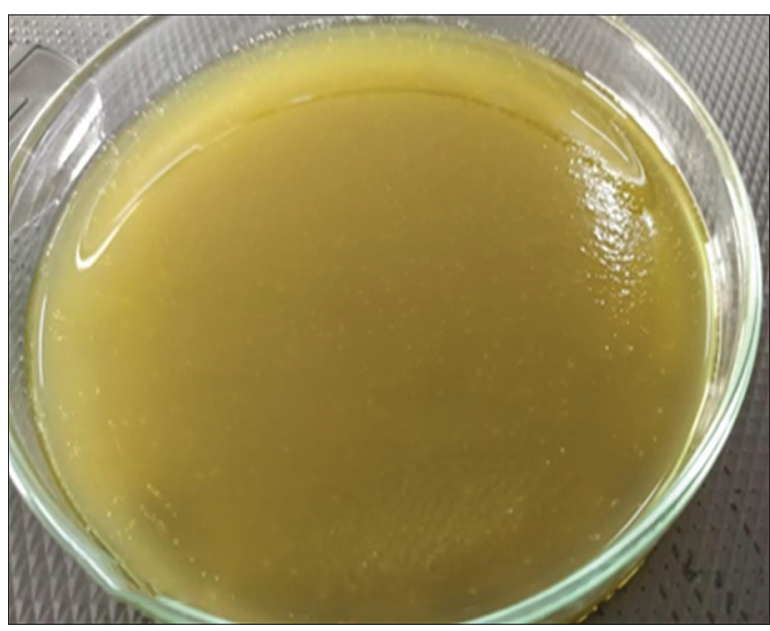

Fig. 3: Hydrogel F3 formulation 
Table 3: Antibacterial activity of Calotropis gigantea leaf-ethanol extract

\begin{tabular}{|c|c|c|c|c|c|c|}
\hline \multirow[t]{3}{*}{ S. No. } & \multirow[t]{3}{*}{ Organism } & \multicolumn{5}{|c|}{ Zone of Inhibition in $\mathbf{~ m m}$} \\
\hline & & \multicolumn{3}{|c|}{ Ethanol leaf extract } & \multirow[t]{2}{*}{ Chl $(20 \mu g)$} & \multirow[t]{2}{*}{ DMSO and water } \\
\hline & & $20 \mu \mathrm{g}$ & $10 \mu \mathrm{g}$ & $0.5 \mu \mathrm{g}$ & & \\
\hline 1. & Staphylococcus aureus & $17 \pm 0.02$ & $14 \pm 0.02$ & $13 \pm 0.02$ & $21 \pm 0.07$ & Nil \\
\hline 2. & Pseudomonas aeruginosa & $16 \pm 0.03$ & $13 \pm 0.03$ & $12 \pm 0.01$ & $17 \pm 0.04$ & \\
\hline 3. & Escherichia coli & $16 \pm 0.04$ & $14 \pm 0.03$ & $12 \pm 0.02$ & $17 \pm 0.02$ & \\
\hline 4. & Klebsiella pneumonia & $17 \pm 0.03$ & $16 \pm 0.02$ & $14 \pm 0.02$ & $20 \pm 0.06$ & \\
\hline 6. & Enterococcus faecalis & $9 \pm 0.01$ & NOD & NOD & $15 \pm 0.03$ & \\
\hline 7. & Serratia $s p$ & $10 \pm 0.02$ & $9 \pm 0.02$ & NOD & $18 \pm 0.02$ & \\
\hline
\end{tabular}

Chl: Chloramphenicol act as a positive control; Water as negative control, NOD-No Zone Detected; Values are expressed as mean \pm standard deviation of the three replicates. Zone of inhibition not include the diameter of the well

Table 4: Antibacterial activity of Calotropis gigantea butanol leaf extract

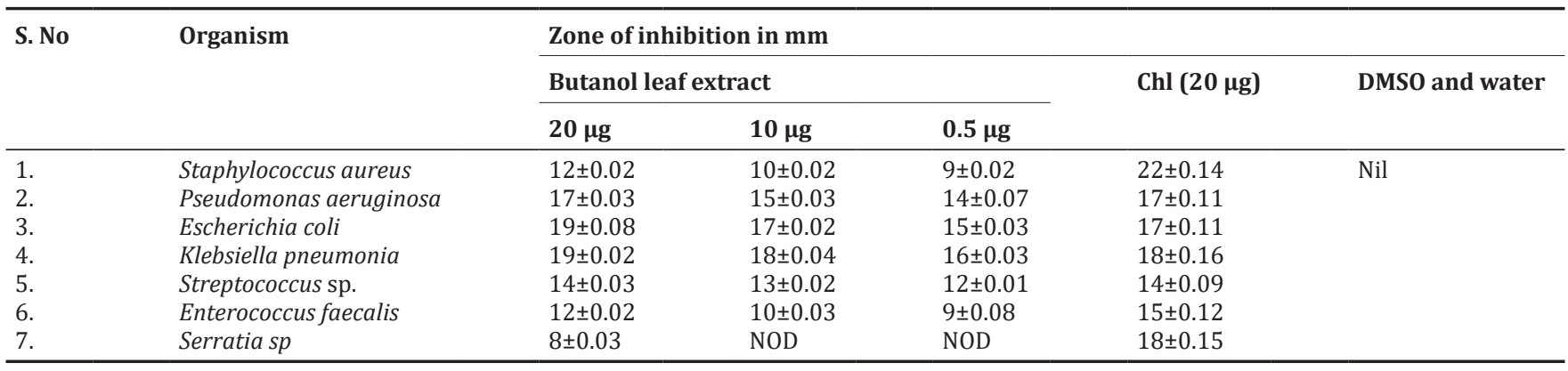

Chl: Chloramphenicol act as a positive control; water as negative control, NOD-No Zone Detected. Values are expressed as mean \pm standard deviation of the three replicates. Zone of inhibition not include the diameter of the well

Table 5: Antibacterial activity of Calotropis gigantea acetone leaf extract

\begin{tabular}{|c|c|c|c|c|c|c|}
\hline \multirow[t]{3}{*}{ S. No. } & \multirow[t]{3}{*}{ Organism } & \multicolumn{5}{|c|}{ Zone of inhibition in $\mathbf{~ m m}$} \\
\hline & & \multicolumn{3}{|c|}{ Acetone leaf extract } & \multirow[t]{2}{*}{ Chl $(20 \mu g)$} & \multirow[t]{2}{*}{ DMSO and water } \\
\hline & & $20 \mu \mathrm{g}$ & $10 \mu \mathrm{g}$ & $0.5 \mu \mathrm{g}$ & & \\
\hline 1. & Staphylococcus aureus & $18 \pm 0.04$ & $10 \pm 0.09$ & $6 \pm 0.09$ & $12 \pm 0.12$ & Nil \\
\hline 2. & Pseudomonas aeruginosa & $9 \pm 0.06$ & $8 \pm 0.06$ & NOD & $17 \pm 0.15$ & \\
\hline 3. & Escherichia coli & $10 \pm 0.09$ & $8 \pm 0.03$ & $9 \pm 0.05$ & $17 \pm 0.09$ & \\
\hline 4. & Klebsiella pneumoniae & $9 \pm 0.07$ & $4 \pm 0.02$ & NOD & $20 \pm 0.16$ & \\
\hline 5. & Streptococcus pyogenes & $9 \pm 0.06$ & $4 \pm 0.03$ & NOD & $14 \pm 0.12$ & \\
\hline 6. & Enterococcus faecalis & NOD & NOD & NOD & $15 \pm 0.10$ & \\
\hline 7. & Serratia sp & NOD & NOD & NOD & $18 \pm 0.11$ & \\
\hline
\end{tabular}

Chl: Chloramphenicol act as a positive control; Water as negative control, NOD-No Zone Detected. Values are expressed as mean \pm standard deviation of the three replicates

Table 6: Physical parameters of formulation

\begin{tabular}{llllll}
\hline S. & Formulation & Color & Odor & Homogeneity & pH \\
No. & & & & & \\
\hline 1. & F1 & Light green & Stable & Good & $7.2 \pm 0.03$ \\
2. & F2 & Greenish & Stable & Good & $7.0 \pm 0.05$ \\
3. & F3 & Greenish & Stable & Good & $6.8 \pm 0.02$ \\
\hline
\end{tabular}

Table 7: Spreadability of the Formulation

\begin{tabular}{lllll}
\hline S. No & Formulation & Mean time & Spreadability & \% drug content \\
\hline 1. & F1 & $5.8 \pm 0.03$ & $25.8 \pm 0.21$ & $61.2 \pm 0.38$ \\
2. & F2 & $5.5 \pm 0.02$ & $29.09 \pm 0.17$ & $68.3 \pm 0.42$ \\
3. & F3 & $5.0 \pm 0.04$ & $34.0 \pm 0.28$ & $75.2 \pm 0.55$ \\
\hline
\end{tabular}

Isolation and purification of active phytochemicals from the calotropis gigantean

The ethanolic and butanolic leaf extracts evident the excessive quantity of alkaloid, flavonoid and saponins than the acetone extract which evidenced the presence of alkaloid alone. This supports the earlier findings of
Ogbulie [11] that ethanol and butanol are the best solvent for the extraction of plant bioactive principles of medicinal importance (Table 2).

Antibacterial activity of Calotropis gigantea leaf extract against clinical isolates

The result showed that there is no antimicrobial activity of the leaf water extract and the leaf DMSO extract (Table 3). The ethanol extract of $C$. gigantea leaves exhibited the antibacterial activity against seven clinical isolates of bacteria (Tables 3 and Fig. 1) and the results were expressed as mean \pm standard deviation $(n=3)$. Extract showed maximum antibacterial activity against Streptococcus sp. $(22 \pm 0.06)$ and the lowest activity against Enterococcus faecalis $(9 \pm 0.01)$. This result supports the earlier studies of Meenakshi Sharma [12]

The zone of inhibition (Table 4 and Fig. 2) of butanol leaf extract against seven clinical isolates was ranged from $8 \mathrm{~mm}$ to $19 \mathrm{~mm}, 10 \mathrm{~mm}$ to $18 \mathrm{~mm}, 9 \mathrm{~mm}$ to $16 \mathrm{~mm}$ for $20 \mu \mathrm{g}, 10 \mu \mathrm{g}$, and $0.5 \mu \mathrm{g}$, respectively. In which the wide zone of inhibition $(19 \pm 0.02)$ against Klebsiella pneumoniae than the positive control antibiotic chloramphenicol, whereas the other organisms showed a lesser zone of inhibition than the control antibiotic. 
Zone of inhibition not includes the diameter of the well

The antibacterial activity of acetone exact reveals a different scenario against clinical isolates. Even though acetone is a disinfectant on its own their bactericidal property, it has been evidenced when it used as solvent. The zone of inhibition (Table 5) of acetone leaf extract against seven clinical isolates was ranged from $9 \mathrm{~mm}$ to $18 \mathrm{~mm}, 4 \mathrm{~mm}$ to $10 \mathrm{~mm}, 6 \mathrm{~mm}$ to $\mathrm{mm}$ for $20 \mu \mathrm{g}, 10 \mu \mathrm{g}$, and $0.5 \mu \mathrm{g}$, respectively. In which the wide zone of inhibition $(18 \pm 0.04)$ against Staphylococcus aureus than the positive control antibiotic chloramphenicol. However, there were no zone of inhibition observed against Enterococcus faecalis and Serratia sp. However, the leaf extract of Calotropis gigantea was found to effective against the foot ulcer causing organisms such as Staphylococcus aureus, Klebsiella pneumonia, and Streptococcus sp. [13].

\section{Development of hydrogel and evaluation of their properties}

The hydro gel was light greenish in color with stable odor and at pH 7.2. It also showed good consistency and homogeneity (Fig. 3). Spreadability and drug content of gel was measured and tabulated (Tables 6 and 7).

\section{Development of hydrogel and evaluation of their properties}

In the present study, the ethanolic extract of $C$. gigantea was revealed more effective than other extract preparation. This might be due to the polar nature of the solvent, that is, ethanol, which resulted in leaching of more active ingredients during extraction for antimicrobial active substance from Calotropis compared to other solvents. Since only one more study is there on the preparation of hydro gel using Calotropis gigantea leaf extract. From the result it is clear that all the gel formulation shows good gelling properties such as homogeneity and consistency. The $\mathrm{pH}$ (Table 7) of all formulations was in the range of compatible $(6.8 \pm 0.02)$ with normal $\mathrm{pH}$ range of the skin. The drug content released was also above average. Thus the gel formulation has all the desirable properties of an ideal gel formulation. The result shows that the hydrogel developed from Calotropis gigantea has probable solutions that could pave way for the new drug development against the foot ulcer occurring in the diabetes. Our results support overall in vitro antibacterial activity of the extracts that may prove to be of clinical importance in improving the management of bacterial recurrent infection in diabetic patients.

\section{CONCLUSION}

The medicinal property of Calotropis gigantea was best studied. It evident the antibacterial activity against bacteria which has been isolated from the foot ulcer of diabetics. Hydrogel formulation was tried and prepared from the leaf extract of Calotropis gigantea. Foot ulcer causing organisms such as Staphylococcus aureus, Streptococcus sp, and Klebsiella pneumoniae growth were inhibited significantly.

\section{ACKNOWLEDGMENT}

The authors would like to acknowledge the Host Institution Dr.N.G.P. Arts and Science College, Coimbatore for their moral, financial, and infrastructural support and Research Facilities by DBT - FIST, DBT - STAR Scheme and DST. We also thankful to our management,
Principal, Deans of different portfolio, HOD of Microbiology and collogues for their valuable advices during article writing. (Communicatin No.:Dr. NGPASC 2019-20 BS027).

\section{AUTHORS CONTRIBUTION}

All the authors contributed to the preparation of the final manuscript.

\section{CONFLICT OF INTEREST}

There is no conflict of interest

\section{AUTHORS FUNDING}

The authors did not receive any funding for this work.

\section{REFERENCES}

1. Jneid J, Lavigne J, La Scola B, Cassir N. The diabetic foot microbiota: A review. Hum Microbiome J 2017;5:1-6.

2. Kumar G, Karthik L, Rao KV. Antibacterial activity of aqueous extract of Calotropis gigantea leaves-an in vitro study. Int J Pharm Sci Rev Res 2010;4:141-2.

3. Eziuzo OS, Amarauche C. Studies on sida acuta hydrogel I: Processing and physicochemical properties of the derived hydrogel obtained from South East Nigeria. IJPPS 2017;9:5-11.

4. Mikail HG. Phytochemical screening elemental analysis and acute toxicity of aqueous extract of Allium satiivum L. Bulb in experimental rabbits. J Med Plant Res 2010;4:322-6.

5. Kalaiselvi V, Binu TV, Radha SR. Preliminary phytochemical analysis of the various leaf extracts of Mimusops Elengi L. South Indian J Biol Sci 2016;2:24-9.

6. Edy HJ, Marchaban, Wahyuono S, Nugroho AE. Formulation and evaluation of hydrogel containing Tagetes erecta L. leaves ethanolic extract. Int J Curr Innov Res 2017;3:627-30.

7. Manivannan R, Shopna R. Antidiabetic activity of calotropis gigantea white flower extracts in alloxan induced diabetic rats. J Drug Deliv Ther 2017;7:106-11.

8. Shobowale OO, Ogbulie NJ, Itoandon EE, Oresegun MO, Olatope SOA. Phytochemical and antimicrobial evaluation of aqueous and organic extracts of calotropis procera A it leaf and latex. NIFOJ 2013;31:77-82.

9. Ogbulie JN, Ogueke CC, Nwanebu FC. Antibacterial properties of Uvaria chamae, Gongronema latifolium, Garcinia kola, vemonia amygdalina and aframomium melegueta. Afr J Biotechnol 2007; 13:1549-53.

10. Shah MD, Iqbal M. Antioxidant activity, phytochemical analysis and total polyphenolics content of Essential oil, methanol extract and methanol fractions from commelina nudiflora. Int J Pharm Pharm Sci 2018;10:36-43.

11. Sharma M, Tandon S, Aggarwal V, Bhat KG, Kappadi D, Chandrashekhar P, et al. Evaluation of antibacterial activity of Calotropis gigantea against Streptococcus mutans and Lactobacillus acidophilus: An in vitro comparative study. J Conserv Dent 2015;18:457-60.

12. Patil SV, Roshan R, Mane RR. Bacterial and clinical profile of diabetic foot ulcer using optimal culture techniques. Int J Res Med Sci 2017;5:496-502.

13. Bansal E, Garg A, Bhatia S, Attri AK, Chander J. Spectrum of microbial flora in diabetic foot ulcers. Indian $\mathrm{J}$ Pathol Microbiol 2008;51:204. 